\title{
Human-Robots And Google Translate: A Case Study Of Translation Accuracy In Translating French-Indonesian Culinary Texts
}

\section{Muhammad Hasyim¹, Ade Yolanda Latjuba², Andi Muhammad Akhmar ${ }^{3}$, Kaharuddin ${ }^{4}$, Noer Jihad Saleh ${ }^{5}$}

hasyimfrance@unhas.ac.id ${ }^{1}$

adeyolanda@unhas.ac.id ${ }^{2}$

akhmar@unhas.ac.id ${ }^{3}$

kaharuddintitiek@gmail ${ }^{4}$

noerjihadsaleh239@gmail.com

${ }_{1,2,3,4}$ Cultural sciences Faculty, Hasanuddin University, Indonesia

Article History:Received:11 January 2021; Accepted: 27 February 2021; Published online: 5 April 2021

\begin{abstract}
Google Translate (GT) is the most widely used translator application in the world. The function of GT is not merely as tools but has become a means in personal communication, learning and business matters. This paper aims to examine the GT accuracy in translating culinary texts. This paper used a semiotic approach to analyze the equivalence of GT from the source language to the target language. The data source as the object of study is French culinary texts retrieved from the internet. It can be concluded that the accuracy of GT in culinary texts lies in words, phrases and sentences. GT does not yet have good accuracy in translating culture between source and target languages. In the semiotic perspective, the GT translation model is the translation from the source language form to the target language form (signifier) by maintaining the concept (meaning). GT does not yet have a translation feature in a cultural context. The advancement in information technology shows that GT, as a human-robot, can replace human translators.
\end{abstract}

Keywords: human-robot, Google translation, accuracy, culinary texts, semiotic

\section{INTRODUCTION}

Hootsuite.com survey reveals that the number of smartphone users in the world in January 2021 reached 5.22 billion and internet users were 4.66 billion people. Most internet users are using social media, reaching 4.2 billion people. The report reveals that as of January 2021, with the world's population reaching 7.83 billion people, the percentage of internet users is 66.6 per cent of the world's population. The results of this survey show that digital media like the smartphone has become a gateway to information (Wardani, 2021). Digital media has enabled people in the world to communicate and interact with each other between various countries with different languages.

An interesting phenomenon in the development of internet-based digital media is that the language barrier is no longer becoming the main obstacle in communicating and interacting. Humans no longer need human translators who have been a prerequisite for communication. The information age has introduced artificial intelligence (robot) to replace the role of humans (Liu, Wang, \& Wang, 2020; Demir, M., McNeese, N.J., Cooke, N.J. 2020; Malik \& Brem, 2021). One example is a translation application. Of many translation applications available on the internet, google translate (GT) is the most widely used by internet users (Çimke \& Gürkan, 2020; Stapleton \& Kin; Cancino \& Panes, 2021).

One of Google co-founders, Sergey Brin, has recognized the role of machine translators as a medium of communication between countries. Brin himself had received a message in Korean and he could not understand the contents of the message. Finally, Brin tried to use GT from Korean to English (Zainuddin, 2017). Since then, he realized that machine translators like GT have been able to aid humans in communicate and interact with each other across countries. Finally, B-rin developed the GT application in Windows and Android versions.

Google company has improved GT with GMNT (Google Neural Machine Translation) technology. With GMNT technology, GT has been able to match the human translation. Based on a survey conducted by Google in 2016, GT could translate texts with an accuracy level equivalent to human translators. GT has been tested in translating Spanish, Chinese and French to English and vice versa. The texts used for the sample translation were taken from Wikipedia. The translation results using GT show that on a scale of 0 - 6, GT reaches an average value of 5.43. This number has a slight difference from the human translation score of 5.55. This concludes that the GT with GMNT technology has an accuracy of 64 to 87 per cent compared to the previous engine technology (PBMT). 
According to Google, the GMNT version of the GT has a high level of accuracy that can match human translation (Widiatanto, 2016).

The improvement of GT technology is evidenced by the increasing number of GT users in the world. Google translation application users have reached 600 million people in 2018. More than 90 per cent of GT users come from outside the USA (Pertiwi, 2018). One of the ten countries with the most GT users in Indonesia, with growth in GT users reaching more than 300 per cent. They use GT to communicate, seek information (knowledge) and learn in schools and colleges (Jumatulaini, 2020). GT is also used as a learning medium for translating foreign news items (Al Ayubi, 2017). GT as a communication medium has been attested in one of the hospitals in Spain. Hospitals in this country have used GT as a communication medium with patients because of patients limited English language skills in the emergency room. Besides, many hospitals in Spain do not have a formal mechanism for written translation, so they use machine translators, such as GT, to provide services to patients. Based on the survey results on the use of GT in hospitals in Spain, it can be concluded that machine translation in Spanish and Chinese showed a very high level of accuracy of Google translation. GT has enabled hospital staffs and patients to communicate and interact with each other (Kreger et al., 2019).

Research on the accuracy of GT in translating foreign languages to Indonesian and vice versa has been conducted. For example, the accuracy of GT in translating text from Indonesian to German (Santoso, 2010). The results of his research concluded that the GT process is still at the pre-translation stage which requires revision. Another study is the analysis of the accuracy of Google Translate using the Back Translation Method (Friday, 2020). This study analyzes the accuracy of GT in translating from Arabic newspaper text to Indonesian text. This study concludes that the accuracy of GT for newspaper texts from Arabic to Indonesian is inaccurate, the reader can understand the meaning of the translated text. This thesis research focuses on analyzing the accuracy level of GT in translating narrative texts, exposition texts and discussion texts from English-Indonesian and Indonesian-English (Nadhianti, 2016). The conclusion of this study indicates that the results of GT in English - Bahasa and vice versa are considered inaccurate.

Research on the accuracy of GT results in translating from foreign languages to Indonesian provides the conclusion that GT is considered inaccurate. This paper analyzes the accuracy of GT in translating culinary texts on internet media in French. The selection of culinary texts as the object of study is that culinary text is one of the teaching materials in tourism school learning and translation course in universities. The GT analysis of French culinary texts (recipes) was carried out using a semiotic approach. The reason for using semiotic theory is to reveal the meaning as a sign that is transferred from the source language to the target language.

\section{Google Translate Application and Semiotics}

Google application as a search engine was first developed in 1996 by Larry Page and Sergey Brin. (Costa, Ha, Lee, 2021). Page and Sergey, who are still students in the USA, developed Google to provide various facilities, a search engine for web addresses, images, videos, books, research results, scholarships and a translating machine, Google Translate. Page and Sergey realized the importance of machine translation to make it easier to understand data discovery on the internet, the two students developed GT using GMNT technology. GT, as an automatic translation machine, was created to help internet users easily and quickly translate information found on websites. GT is very useful along with a large number of web pages in cyberspace that require translation. GT uses GMNT technology which can translate documents, texts or web pages into other languages. Initially, GT was able to provide facilities for translating text from English into German, French and Spanish, and vice versa. Along with the number of websites from various countries using their languages, currently, GT has upgraded its facilities by being able to translate more than 100 languages in the world (Ulfah, 2015).

With GMNT technology, GT developed into a complete MT. There has been a lot of research being done to analyze it. Stephen Doherty (2016) has researched by testing the accuracy of several translation applications. The results of his research concluded that GT is the MT in the highest rank of the ten MTs studied. GT has the best translation system compared to others and is suitable for use as a professional MT.

Many researchers, especially in the field of linguistics, have developed translation theories. If we refer to the concept of translation, the essence of translation is to transfer information from one language as the source language to another as the target language. The purpose of translation is to make speakers of the target language understand or comprehend the information transferred to the language that is understood (mastered) by the speaker. According to Catford (1965), translation is the process of changing text from one language to another. The translation is an activity to transfer text. Nida and Taber (1982) also provide the concept of translation by emphasizing the equivalence of meaning (natural meaning) in the source and target languages. The concept of Nida and Taber explains that speakers of the source language and target language are as close as possible to the same understanding of the information transferred. Another concept of translation was put forward by Larson (1989) by saying that translation is an activity to re-expressing the same meaning using lexicons and appropriate grammatical 
structures in the target language and cultural context. Referring to the opinions of these figures, the keywords for translation activities are the same or closest meaning (context) that is obtained by speakers of the target language.

A scientific problem is what about machine translators. Does the machine translator also apply the concept of translation as stated by the experts in the field of translation? Machine translation (MT) also transfers information from the source language to the target language using an application. This means that machine translation functions as a human-robot (artificial intelligence) and can replace the role of human translators. Because MT is an application, anyone can use although the user does not master a foreign language (source language). The point is how internet users with the help of MT can understand information sourced from foreign languages. The pragmatic goal of MT is how to make internet users understand various information they are searching for on the internet.

In linguistics, MT is a field of computational linguistics that investigates the use of applications in translation activities (Giavazzi et al., 2018; Liu et al., 2021). MT is equipped with vocabulary and grammar. The task of MT is converting words, phrases and grammar from one language to another (Malgaroli et al., 2020). Like GT, this machine translator can translate text up to 5000 characters in real-time. This is one of the advantages of MT which can translate text up to 5000 characters at a time compared to human translators.

The semiotic perspective examines MT from the aspects of form (signifier) and meaning (signified). As has been stated by Larson (1989) that translation activities are the re-expressing of meanings from different languages. Thus, the information in the form of text that is displayed visually from one language is the signifier (form) and the meaning of the information transferred is a sign (meaning).

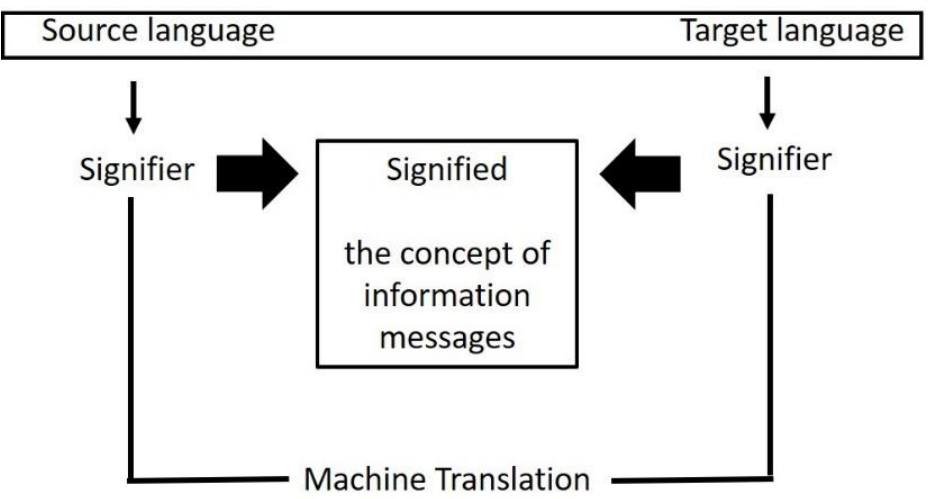

Figure 1. The machine translation semiosis process

The process of transferring text information from the source language into the target language is a semiotic process involved signs, signifier and signified. The signifier is a physical record of information messages in certain media, signified is a concept generated by signified (physical records of information messages) and signs are the association of signifier and signified that is referred to as signification (Hasyim et al., 2021). Semiotically, the translation of MT is an activity of transferring signs (meaning) that occurs semiotically between the signifier and signified (Hasyim et al., 2020). In MT translation, a signifier is a physical record of information and signified is a concept (meaning) of a physical record of information. The MT process is to reveal the meaning (signified) of the physical record of an information message from the source language to the target language. Signifier in the target language is the result of transferring signifier (information messages) and signified is the result of re-expressing the same meaning and closest to the source language.

Readers (internet users) get information on the internet and mediated by MT to gain understanding. The transfer of information by MT is accepted by the reader as information resulting from the translation (target language). The process of MT semiosis is to re-expressing the meaning as signified (concept) from the source language as a signifier (form) and to the target language as a signifier (form). Signifier (physical records of informational text) from the source language is transferred to different signifiers in the target language by maintaining the natural meaning or as close as possible to produce the same or close understanding between the readers of the source language and the target language. For example, the concept "tree" in English and Indonesian. The signifier in English is "tree" and the signifier in Indonesian is "pohon". However, both languages use the same concept (meaning) about trees. Translation in a semiotic perspective is the re-expressing of meaning (signified) with a different signifier (source language-target language). The role of MT as a robotic human is to transfer information 
from one language as a source to another. Anything transferred by MT will be accepted by readers as an interlingual translation process (Hasyim, Nursidah \& Hasjim, 2019).

MT is an Artificial Intelligence (AI) that simulates human intelligence using programs (applications) that can work and mimic human actions. MT as AI is a human-robot that already has a system that can be controlled by users (Stapleton and Kin, 2019; Lester et al., 2021). MT works by replacing the human role as a translator which is more practical, efficient and economical (does not cost a lot of money and even free).

\section{RESEARCH METHOD}

We used a qualitative research method that aims to perform an accurate analysis description of GT (Burhanuddin \& Hashim, 2019). The primary data used was French culinary texts (recipes) and retrieved on the internet. We take one example of a culinary text for analysis.

The data analysis of this research was to select one recipe text and mark vocabulary related to culinary themes, complex sentence structures and cultural contexts. In conducting the analysis, we collect the vocabulary in the recipes and find their translation in the French-Indonesian dictionary. The goal is to know the translation method used. The analysis procedure is that the prescription text is input to the source language column and takes the translation results from the column provided by GT. The translation results are input to the table in the source language and target language columns.

Recipes being analyzed entitled:

\section{Soupe au potiron : la meilleure recette}

Ingrédients:

Potiron, $1 / 4$

Bouillon de volaille, $50 \mathrm{cl}$

Croûton

Persil

Poivre

Pomme de terre, 8

Crème fraîche, $200 \mathrm{~g}$

Noix de muscade

Sel

\section{Préparation:}

1. Enlever la peau et la partie filandreuse du potiron pour ne conserver que la pulpe. Couper la pulpe grossièrement en gros morceaux $(3 \mathrm{~cm} \times 3)$. Éplucher les pommes de terre.

2. Faire cuire à la vapeur potiron et pommes de terre (dans l'autocuiseur et ensemble c'est plus simple). Parallèlement, faire chauffer le bouillon de volaille.

3. Passer potiron et pommes de terre ensemble au mixeur en ajoutant régulièrement du bouillon bouillant.

4. Reverser le mélange ainsi obtenu dans une casserole. Ajouter la crème, mélanger, assaisonner (sel, poivre, muscade) et porter à ébullition.

5. Aux premiers bouillons, retirer la soupe, la servir dans une jolie soupière avec du persil grossièrement haché.

6. Pour finir: Sur table, proposer des petits croûtons aux amateurs

(Source: https://cuisine.journaldesfemmes.fr/recette/208275-soupe-au-potiron)

\section{RESULTS AND DISCUSSION}

The analysis results on GT accuracy can be divided into two parts, including the equivalence of terms (vocabulary) consisting of nouns and verbs, sentence structures and cultural translations. The translation of noun categories is the ingredients of pumpkin soup, the verbs and sentence structures found in the pumpkin making preparations. Meanwhile, the cultural translation for context or equivalence.

\begin{tabular}{|l|l|}
\hline \multicolumn{1}{|c|}{ Source text (French) } & \multicolumn{1}{c|}{ Target text (Indonesian) } \\
\hline Ingrédients & Bahan (Ingredients) \\
\hline Potiron, $1 / 4$ & Labu, $1 / 4$ (Pumpkin, $1 / 4)$ \\
\hline Bouillon de volaille, $50 \mathrm{cl}$ & Kaldu unggas, $50 \mathrm{cl}$ (Poultry broth, $50 \mathrm{cl}$ ) \\
\hline Croûton & Crouton (Crouton) \\
\hline Persil & Peterseli (Parsley) \\
\hline
\end{tabular}


Human-Robots And Google Translate: A Case Study Of Translation Accuracy In Translating FrenchIndonesian Culinary Texts

\begin{tabular}{|c|c|}
\hline Poivre & Lada (Pepper) \\
\hline Pomme de terre, 8 & Kentang, 8 (Potato, 8) \\
\hline Crème fraîche, $200 \mathrm{~g}$ & Krim segar, $200 \mathrm{~g}$ (Fresh cream, $200 \mathrm{~g}$ ) \\
\hline Noix de muscade & Pala (Nutmeg) \\
\hline Sel & Garam (Salt) \\
\hline Préparation & Persiapan (preparation) \\
\hline $\begin{array}{l}\text { Enlever la peau et la partie filandreuse du potiron } \\
\text { pour ne conserver que la pulpe. Couper la pulpe } \\
\text { grossièrement en gros morceaux }(3 \mathrm{~cm} \text { x } 3) \text {. } \\
\text { Éplucher les pommes de terre. }\end{array}$ & $\begin{array}{l}\text { Buang kulit dan bagian yang berserabut dari labu } \\
\text { untuk menyimpan hanya ampasnya. Potong kasar } \\
\text { daging buah menjadi potongan besar ( } 3 \mathrm{~cm} \times 3) \text {. } \\
\text { Kupas kentang (Remove the skin and the stringy } \\
\text { part of the pumpkin to keep only the pulp. Roughly } \\
\text { cut the pulp into large pieces ( } 3 \mathrm{~cm} \times 3) \text {. Peel } \\
\text { potatoes). }\end{array}$ \\
\hline $\begin{array}{l}\text { Faire cuire à la vapeur potiron et pommes de terre } \\
\text { (dans l'autocuiseur et ensemble c'est plus simple). } \\
\text { Parallèlement, faire chauffer le bouillon de volaille. }\end{array}$ & $\begin{array}{l}\text { Kukus labu dan kentang (di dalam panci presto dan } \\
\text { lebih mudah bersama-sama). Pada saat bersamaan, } \\
\text { panaskan kaldu ayam (Steam the pumpkin and } \\
\text { potatoes (in the pressure cooker and together it's } \\
\text { easier). At the same time, heat the chicken broth). }\end{array}$ \\
\hline 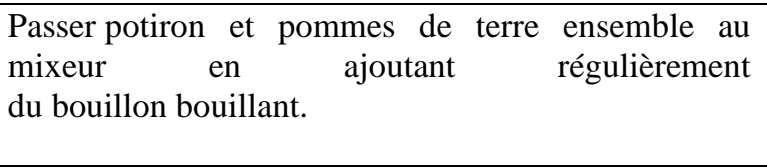 & $\begin{array}{l}\text { Masukkan labu dan kentang ke dalam blender, } \\
\text { tambahkan kaldu mendidih secara teratur (Pass the } \\
\text { pumpkin and potatoes together in a blender, } \\
\text { regularly adding boiling broth). }\end{array}$ \\
\hline $\begin{array}{l}\text { Reverser le mélange ainsi obtenu dans une casserole. } \\
\text { Ajouter la crème, mélanger, assaisonner (sel, poivre, } \\
\text { muscade) et porter à ébullition. }\end{array}$ & $\begin{array}{l}\text { Tuang kembali campuran yang dihasilkan ke dalam } \\
\text { panci. Tambahkan krim, aduk, bumbui (garam, } \\
\text { merica, pala) dan didihkan (Pour the resulting } \\
\text { mixture back into a saucepan. Add the cream, mix, } \\
\text { season (salt, pepper, nutmeg) and bring to a boil). }\end{array}$ \\
\hline $\begin{array}{l}\text { Aux premiers bouillons, retirer la soupe, la servir } \\
\text { dans une jolie soupière avec du persil } \\
\text { grossièrement haché. }\end{array}$ & $\begin{array}{l}\text { Pada kaldu pertama, angkat sup, sajikan dalam sup } \\
\text { mangkok cantik dengan peterseli cincang kasar (At } \\
\text { the first broth, remove the soup, serve it in a pretty } \\
\text { soup tureen with coarsely chopped parsley). }\end{array}$ \\
\hline $\begin{array}{l}\text { Pour finir: Sur table, proposer des petits croûtons aux } \\
\text { amateurs }\end{array}$ & $\begin{array}{l}\text { Selesai: Di atas meja, tawarkan crouton kecil untuk } \\
\text { para amatir (To finish: On the table, offer small } \\
\text { croutons to amateurs) }\end{array}$ \\
\hline
\end{tabular}

\section{Translation of terms (Vocabulary)}

Table 1. Source text and target text

The translation of terms is associated with the equivalent concept of vocabulary. The definition of the term itself is a collection of vocabulary in certain fields, for example, terms in the culinary field. Panaou (2013) defines translation equivalent as the equivalent of the source text with target text and another definition is the relationship between words or phrases from two languages that have the same meaning (Liu, 2018). Russel (1959) describes a definition from a semiotic perspective (1959) that we cannot understand the word 'cheese' unless we have a nonlinguistic acquaintance with cheese. To understand the word "cheese" as a signifier in English, we must link the nonlinguistic language "cheese" as an object (referent), which becomes a signified in someone's mind. The relationship between the sign and its object (something beyond the human being) is called nonlinguistic acquaintance. According to Jacobson (2012), there is no signatum (signified) without signum (signifier). Signatum and signum are the relations that form (produce) signs.

Translation by utilizing GT on the vocabulary of pumpkin soup recipe ingredients in table 1 shows high accuracy. There are eight vocabularies, which are common culinary terms, showing GT accuracy in translation reaching 90 per cent. This means that out of the eight terms translated, there is only one term, 'croûton' which cannot be translated. In the French-Indonesian dictionary, the word means "crusty white bread" (www.dict.com). It means that word croûton has not included in the GT word lists.

We have tested the translation of the eight vocabularies based on context by checking them in the FrenchIndonesian dictionary. The result is that GT can recognize the context of translating the culinary field. 
Muhammad Hasyim ${ }^{1}$, Ade Yolanda Latjuba ${ }^{2}$, Andi Muhammad Akhmar ${ }^{3}$, Kaharuddin ${ }^{4}$, Noer Jihad Saleh $^{5}$

\begin{tabular}{|l|l|l|}
\hline \multicolumn{1}{|c|}{ Source text (French) } & GT Indonesian & Dictionary of French-Indonesia $^{\mathbf{1}}$ \\
\hline Potiron & Labu & \\
\hline Bouillon de volaille & Kaldu unggas & $\begin{array}{l}\text { Kaldu, air daging, kuah, ungags, } \\
\text { ayam itik }\end{array}$ \\
\hline Croûton & Crouton & Kerak roti tawar \\
\hline Persil & Peterseli & Peterseli, daun sup \\
\hline Poivre & Lada & Lada, merica \\
\hline Pomme de terre & Kentang & Kentang \\
\hline Crème fraîche & Krim segar & Krim segar, dingin, sejuk \\
\hline Noix de muscade & Pala & Pala, buah, biji \\
\hline Sel & Garam & Garam, asin (salty) \\
\hline
\end{tabular}

Table 2. Vocabulary (nouns) in source and target texts

The equivalence analysis of verbs in French to Indonesian is carried out on the use of sentences in the cooking preparation section. The commonly used verbs in the culinary field can be seen in table 3 .

\begin{tabular}{|l|l|l|}
\hline \multicolumn{1}{|c|}{$\begin{array}{c}\text { Verbs of the } \\
\text { source text }\end{array}$} & \multicolumn{1}{|c|}{ GT verbs } & \multicolumn{1}{c|}{ Dictionary of French-Indonesia $^{2}$} \\
\hline Enlever & Buang & $\begin{array}{l}\text { melepas, menghilangkan, menggeser, } \\
\text { mencopot, mengeluarkan, membersihkan }\end{array}$ \\
\hline Couper & Potong & Memotong, menggunting, mengiris \\
\hline Éplucher & Kupas & membersihkan, mengupas, menguliti, mengubak \\
\hline Faire cuire & Kukus & Memanggang, membakar, memasak \\
\hline faire chauffer & Panaskan & Memanaskan \\
\hline Passer & Masukkan & Melewati, melewatkan, melalui \\
\hline Ajouter (ajoutant) & Tambahkan & Menambahkan, membubuhi, menambah \\
\hline Bouillir (bouillant) & Mendidih & Mendidih, bergolak \\
\hline Reverser & Tuang kembali & Menuangkan kembali, menaburkan \\
\hline Mélanger & Aduk & Mencampurkan, mengaduk, mencampur \\
\hline Assaisonner & Bumbuhi & Membumbuhi, merempah \\
\hline Porter & Didihkan & Membawa, membawakan, mengajukan \\
\hline Retirer & Angkat & Menarik, mengeluarkan, menghindarkan \\
\hline Server & Sajikan & Menyajikan, melayani, meladeni \\
\hline Proposer & Tawarkan & Mengusulkan, menganjurkan, menyarankan \\
\hline
\end{tabular}

Table 3. Vocabulary (verbs) in source and target texts

The equivalence of nouns and verbs in GT emphasizes context-based meaning in the target language. The translation process is GT may transfer messages by selecting nouns and verbs according to the context of the culinary field (recipes). Thus, GT can translate messages according to context (meaning). The semiotic model in the equivalent of GT in the culinary text is signifier 1 (source language) - signified (contextual meaning) - signifier 2 (target language). GT can recognize the context of the message in the source language and re-expressing the message according to the cultural context.

\section{The Cultural Context in GT}

Culture is closely related to the process of translation. Transferring culture from a source text (ST) to a target text (TT) is a fundamental aspect of the phenomenon of translation (Neshkovska, \& Kitanovska-Kimovska, 2018). With MT currently available on the internet, of course, MT functions as a translator like human translators do and are entrusted with the task of transferring culture and allowing the target text reader to understand the original message in its entirety, just like the source text reader. Human translators often find it difficult to translate terms relating to specific cultures (special terms). What human translators do is classify specific cultures and relate them to

${ }^{1}$ Source: https://www.dict.com/phap-indonesia

${ }^{2}$ Source: https://www.dict.com/phap-indonesia 
translation theory (strategy), for example, adaptation translation, borrowing, explanation, reduction, generalization, etc. Meanwhile, MT is a human-robot that has been equipped with a translation technology system that also has the function of transferring information including the cultural context. The MT accuracy in cultural translation can be tested on the French-Indonesian translation of the culinary text (recipe) in this paper.

The definition of culture that often becomes a reference in translation activities is the way of life, which is manifested through behaviour and habits passed down from generation to generation through the process of habituation and learning in society. As stated by the definition of culture by Newmark (1988) by stating that culture is a way of life and community manifests it in language as a means of expression. Hoed (2006) argues that certain societies have a distinctive culture and because of their uniqueness, no culture is the same. Translation activity in culture is to transfer the cultural equivalents from the source language into the target language. For example, France acknowledges the word 'cuillère à café' (coffee spoon) to stir coffee and tea. Meanwhile, Indonesian uses a teaspoon 'teaspoon', a small spoon to stir tea and coffee. This cultural context difference is because French people have the habit of using a small spoon to stir coffee and Indonesians have the habit of using the word 'teaspoon' for tea drinks.

Choosing the right words in Indonesian, as the target language, shows that GT can transfer the cultural context. GT can choose verbs in command sentences according to the context of the culinary culture. The verbs used can be seen in table 3 and the examples of sentences can be seen in table 1.

Examples of imperative sentences used following the context of culinary culture (cooking) are infinitive verbs into imperative sentences:

Enlever la peau et la partie filandreuse du potiron pour ne conserver que la pulpe. Couper la pulpe grossièrement en gros morceaux $(3 \mathrm{~cm} \times 3)$. Éplucher les pommes de terre.

Buang kulit dan bagian yang berserabut dari labu untuk menyimpan hanya ampasnya. Potong kasar daging buah menjadi potongan besar ( $3 \mathrm{~cm} \times 3)$. Kupas kentang

(Remove the skin and the stringy part of the pumpkin to keep only the pulp. Roughly cut the pulp into large pieces ( $3 \mathrm{~cm} \times 3)$. Peel potatoes).

In the context of Indonesian recipes, the type of sentence used to give instructions for food making or preparation is an imperative sentence. Meanwhile, in the context of French culinary culture uses the infinitive verbs and the command sentence persona Vous (a form of politeness). In translating culinary texts into Indonesian, GT uses imperative sentences as in the context used in Indonesian recipes. Examples of Indonesian cultural versions of pumpkin soup recipes that use imperative sentences, for example 'kukus' (steam), 'tumis' (sauteing), 'sisihkan' (set aside), 'masukkan' (enter), and 'beri' (give).

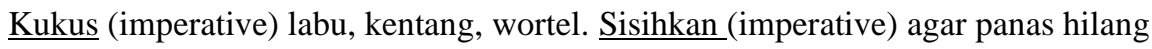

$\underline{\text { Steam }}$ pumpkin, potatoes, carrots. Set aside so that the heat is lost

Masukkan (imperative) kaldu ayam dan daun bawang, kecilkan (imperative) api

Enter the chicken stock and spring onions, reduce the heat

Source: https://cookpad.com/id/resep/5112036-29-pumpkin-soup-sup-labu-kuning

In French culinary texts, GT can acknowledge the cultural context from the source language (French) and the target language (Indonesian). GT can translate not merely words, phrases and sentences with conceptual (meaning) but also cultural equivalents in French-Indonesian culinary texts.

GT as a translation application can certainly add to the vocabulary database (words and phrases), grammar (semantics and syntax) and cultural equivalents by referring to various cases of translation found. Along with the increasing need for translation applications in the world, GT is not merely used to translate verbal texts but also used as a means of communication between individuals, groups and organizations from various countries. This is evidenced by the provision of translation machines such as GT at public facilities, such as airports, supermarkets, and hospitals and in industry 4.0 the role of artificial intelligence technology has increased and slowly takes the human role. Machine translators such as GT, as human robots, are clear evidence that can replace humans' position in translation and communication activities between people.

\section{CONCLUSION}


Many studies that have been conducted on the accuracy of GT have concluded that the GT is inaccurate and that numerous errors are still found. The research on the accuracy of GT for culinary texts from French to Indonesia produces high accuracy. GT can re-express contextual meanings with great accuracy and can perform cultural equivalents. Based on the research results on the accuracy of GT for French-Indonesian culinary texts, we can conclude that the accuracy of machine translation, such as GT, is largely determined by the number of internet users translating culinary texts with GT so that this application can improve the accuracy of the translation results; The source text to be translated by machine uses very general vocabulary and simple sentence structure. This happens in translating French culinary texts. The sentence structure (subject, predicate, object) used in French and Indonesian recipe texts is almost the same which allows GT to perfectly translate culinary texts.

The existing translation theory shows that there are difficulties in translating culture-specific so that translation experts only carry out a strategy of classifying cultural translations (borrowing, adaptation, explanation, reduction, etc.). Also, with MT, this application of course must continue to improve the translation technology system, especially in the specific cultural translation of various nations. Due to cultural diversities from one source language to the target language, MT is equipped with a technology system in the form of techniques or strategies in carrying out cultural translation.

\section{References:}

1. Al-Ayubi, M. Shalehuddin. 2017. Utilization Of Google Translation As A Learning Medium At Foreign News Text Translation. Jurnal Teknodik, 21 (2), 155-166.

2. Arafah, Burhanuddin, Hasyim, Muhammad. 2019. Linguistic functions of emoji in social media communication. Opcion, 35, (24), 558-574.

3. Cancino, M., Panes, J. 2021. The impact of Google Translate on L2 writing quality measures: Evidence from Chilean EFL high school learners. System, 98, 102464.

4. Catford, J.C. (1978). A Linguistic Theory of Translation. Oxford University Press.

5. Costa, C., Ha, J., Lee, S. 2021. Spatial disparity of income-weighted accessibility in Brazilian Cities: Application of a Google Maps API. Journal of Transport Geography, 90, 102905.

6. Çimke, S., Ph.D., Gürkan, D.Y.G., MS.c. 2020. Determination of interest in vitamin use during COVID-19 pandemic using Google Trends data: Infodemiology study. Nutrition, 85, 111138

7. Demir, M., McNeese, N.J., Cooke, N.J. 2020. Understanding human-robot teams in light of all-human teams: Aspects of team interaction and shared cognition. International Journal of Human-Computer Studies, 140, 102436

8. Doherty, Stephen. 2016. The Impact of Translation Technologies on the Process and Product of Translation. International Journal of Communication 10, 947-969 .

9. Giavazzi, M., Daland, R., Palminteri, S., Peperkamp, S., Brugières, P., Jacquemot, C., Schramm, C., Cleret de Langavant, L., Bachoud-Lévi, A. 2018. The role of the striatum in linguistic selection: Evidence from Huntington's disease and computational modeling. Cortex, 109, 189-204

10. Hasyim, M., Nursidah, Hasjim, M. 2019. Online advertising: How the consumer goods speaks to women. Opcion, 35 (89), 826-845.

11. Hasyim, M., Arafah, B., Kuswarini, P. 2020. The new Toraja destination: Adding value 'Toraja coffee' of the sustainable tourism development. IOP Conference Series: Earth and Environmental Science, 2020, 575(1), 012072.

12. Hasyim, Muhammad, Saleh, Firman, Yusuf, Rudy, Abbas, Asriani. 2021. Artificial Intelligence: Machine Translation Accuracy in Translating French-Indonesian Culinary Texts. International Journal of Advanced Computer Science and Applications (IJACSA), 12 (3).

13. Hoed, Benny (1992) Kala dalam Novel: Fungsi dan Penerjemahannya. sebuah kajian tentang penerjemahan Perancis-Indonesia. Yogyakarta: Gadjah Mada University Press.

14. Hole, Y., \& Snehal, P. \& Bhaskar, M. (2018). Service marketing and quality strategies. Periodicals of engineering and natural sciences, 6 (1), 182-196.

15. Jakobson, Roman, (2012). On linguistic aspects of translation. In: Venuti, L. (Ed.), The Translation Studies Reader. 3rd ed. Routledge, London/New York, pp. 126-131.

16. Jumatulaini. (2020). Analisis Keakuratan Hasil Penerjemahan Google Translate dengan Menggunakan Metode Back Translation. Alsuniyat: Jurnal Penelitian Bahasa, Sastra, dan Budaya Arab, 3 (1), 77-87. 
17. Kreger, V., Aintablian, H., Diamond, L., Taira, R.B. 2019. 10 Google Translate as a Tool for Emergency Department Discharge Instructions? Not So Fast! Annals of Emergency Medicine, 74, (4), Supplement, S5-S6

18. Larson, M.L. 1989. Meaning Based Translation: A Guide to Cross-Language Equivalence. Lanham \& London: University Press of Amerika.

19. Lester, C.A., PhD, D., Pharm, Yuting, D.,MS, Li, J., MS, Jiang, Y., PhD, Rowell, B., MA, V.G. Vydiswaran, V., PhD. 2021. Comparing Human versus Machine Translation of Electronic Prescription Directions. Journal of the American Pharmacists Association, Available online.

20. Liu, Lixiang. (2018). Partial equivalences in bilingual dictionaries: Classification, causes and compensations. Lingua, 214, 11-27.

21. Liu, Sichao, Wang, Lihui, Wang, Xi Vincent. 2020. Sensorless haptic control for human-robot collaborative assembly. CIRP Journal of Manufacturing Science and Technology, 32, 132-144.

22. Malik, A.A., Brem, A. 2021. Digital twins for collaborative robots: A case study in human-robot interaction. Robotics and Computer-Integrated Manufacturing, 68, 102092.

23. Malgaroli, M., Hull, T.D., Bantilan, N., Ray, B., Simon, N. 2020. Suicide Risk Automated Detection Using Computational Linguistic Markers From Patients' Communication With Therapists. Biological Psychiatry, 87, (9), Supplement, S444

24. Nadhianti, Melita. 2016. An Analysis of Accuracy Level of Google Translate in English-Bahasa Indonesia and Bahasa Indonesia-English Translations. Thesis. Yogyakarta, English Language and Literature English Education Department Faculty of Languages and Arts Yogyakarta State University.

25. Neshkovska, Silvana, \& Kitanovska-Kimovska, Sonja. 2018. Translating Culture. Horizon International Scientific Journal, A XXII, 165-174.

26. Newmark, Peter. (1988). A textbook of translation. New York: Sanghai Foreign Language Education Press.

27. Peter Newmark, P. 1988. A Textbook of translation. Oxford: Pergamon Press, 1988.

28. Nida E.A., \& Taber C.R. 1982. The theory and practice of translation. Leiden: E.J. Brill.

29. Panou, Despoina. (2013). Equivalence in Translation Theories: A Critical Evaluation. Theory and Practice in Language Studies. 3(1), 1-6.

30. Pertiwi, W. K. 2018. Pengguna Google Translate Melonjak Selama Piala Dunia 2018" dalam https://www.kompas.com/.

31. Russell, Bertrand. (1959). Logical positivism. Revue Internationale de Philosophie.

32. Santoso, Iman. 2010. Analisis Kesalahan Kebahasaan Hasil Terjemahan Google-Translate Teks Bahasa Indonesia Ke Dalam Bahasa Jerman dalam http://eprints.uny.ac.id/id/eprint/2865

33. Stapleton, P., Ka Kin, B.L. 2019. Assessing the accuracy and teachers'impressions of GoogleTranslate: A study of primary L2 writers in Hong Kong. English for Specific Purposes, 56, 18-34.

34. Wardani, A. S., 2021. Pengguna Internet Dunia Tembus 4,66 Miliar, Rata-Rata Online di Smartphone, in https://www.liputan6.com/tekno/read/4469008/pengguna-internet-dunia-tembus-466-miliar-rata-rataonline-di-smartphone

35. Widiatanto, Yoga Hastyadi. 2016. Mesin Penerjemah Makin Mirip Manusia dalam https://tekno.kompas.com/

36. Ulfah, Mariah.2015. An Accuracy Analysis In Indonesian-English Translation Using "Google Translate" Machine Translation (Translation of "Jurnal Walisongo Abstracts Vol. 23 Number 1"). Thesis. Semarang: Islamic Education And Teacher Training Faculty Walisongo State Islamic University.

37. Yogesh Hole et al 2019 J. Phys.: Conf. Ser. 1362012121

38. Zainuddin Ahmad. 2017. Kelahiran Mesin Penerjemah dan Masa Depan Google Translate. dalam https://tirto.id/cxS2. 